POTRET ASUHAN

KEPERAWATAN MATERNITAS

PADA KLIEN DENGAN KANKER SERVIKS MELALUI PENDEKATAN KONSERVASI DAN EFIKASI DIRI

Jurnal Keperawatan dan

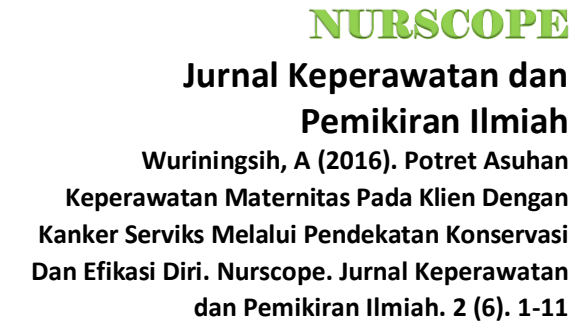

dan Pemikiran IImiah. 2 (6). 1-11

\author{
Apriliani Yulianti Wuriningsih ${ }^{1}$ \\ Fakultas IImu Keperawatan, Universitas Islam Sultan Agung Semarang
}

\begin{abstract}
ABSTRAK
Kanker serviks merupakan salahsatu penyakit kronik pada perempuan dengan berbagai gejala sepanjang hidup pasien. Proses adaptasi terhadap gejala merupakan bagian penting yang menjadi tanggung jawab pasien dengan penyakit kronis seperti kanker serviks. Model konservasi dan efikasi diri membantu perawat melalui kerangka kerja berdasarkan keempat prinsip konservasi yang diintegrasikan dengan keempat komponen efikasi diri. Integrasi kedua model ini dapat mewakili pandangan individu secara holistik, aktif, dan mandiri, serta melibatkan partisipasi secara aktif dari pasien dalam menyusun rencana keperawatan. Hal ini dapat membantu pasien untuk mengelola kehidupannya secara normal agar dapat bertahan dan meningkatkan status kesehatannya.
\end{abstract}

Kata kunci: kanker serviks, integrasi teori konservasi dan efikasi diri.

\title{
PORTRAIT OF SELF EFFICACY AND CONSERVATIONMATERNITY NURSING CARE ON PATIENT WITH CERVICAL CANCER
}

\begin{abstract}
Cervical cancer is one of the main chronic diseases in women with a variety of symptoms throughout the patient's life. The adaptation process of the symptoms is an important part which is the responsibility of patients with chronic diseases such as cervical cancer. Conservation and self-efficacy models can assist nurses through a framework based on four principles of conservation that are integrated with all four components of self-efficacy. The integration of these two models can represent the views of individual holistically, active, and independent, and involves the active participation of the patient in the nursing plan. This can help patients to manage a normal life in order to survive and improve their health status.
\end{abstract}

Keywords: cervical cancer, the integration of conservation and self-efficacy theory.

Corresponding Author:

Apriliani Yulianti Wuriningsih ${ }^{1}$, Fakultas IImu Keperawatan Universitas Islam Sultan Agung, Jalan Raya Kaligawe Km 4, Semarang, Jawa Tengah, Indonesia, Kode pos 50112.

\section{PENDAHULUAN}

Preinvasive kanker serviks biasanya tanpa gejala dan sudah diderita selama $\pm 10-15$ tahun. Pada tahap awal, kanker dapat terdeteksi selama prosedur skrining, namun sebagian besar perempuan memiliki kesadaran yang rendah untuk melakukan pemeriksaan baik melalui test paps smear maupun inspeksi visual dengan asam asetat (IVA) (Miller, Waters, Mody, \& Tams, 2015). Hasil penelitian Gupta, Sitimani, \& Gupta (2015) menunjukkan bahwa dari 171 perempuan yang mengetahui tentang kanker serviks, hanya $24,5 \%$ (42 perempuan) yang melakukan prosedur skrining. 
Perempuan menyadari dirinya menderita kanker serviks setelah mengalami perdarahan vagina abnormal atau keputihan patologis. Pada tahapan ini biasanya kanker serviks sudah memasuki stadium lanjut (Miller, Waters, Mody, \& Tams, 2015; Pandey, Shetty, Sambhaji, Saxena, Mishra, \& Chawla, 2015). Pada tahap akhir kanker serviks menurut Pandey, Shetty, Sambhaji, Saxena, Mishra, \& Chawla (2015) menunjukkan adanya obstruksi ureter akibat penyebaran sel kanker ke arah parametrium, sehingga dapat menyebabkan uremia yang merupakan penyebab paling umum kematian pada kanker serviks.

Di seluruh dunia, kanker serviks menduduki peringkat keempat keganasan setelah kanker payudara, kolorektal, dan kanker paru-paru. Hasil survei menunjukkan bahwa insiden kanker serviks 527.600 kasus baru dan 265.700 kematian setiap tahunnya (Torre, Bray, Siegel, Ferlay, Lortet, \& Jemal, 2012). Kanker serviks menurut Asiedu, Breitkopf (2014); Bermudez, Bhatla, \& Leung (2015) merupakan kasus kedua paling sering dalam penegakkan kasus diagnosis kanker dan penyebab umum ketiga kematian kanker pada perempuan di Negara berkembang. Hal ini terutama terjadi pada penduduk dengan tingkat ekonomi dan sumber daya rendah mencapai lebih dari $85 \%$ baru terdiagnosis dan kematian akibat kanker serviks mencapai $90 \%$.

Di Asia Tenggara, kejadian kanker serviks mencapai 20-30 \% dari semua kanker (Bal, Goyal, Suri, \& Mohi, 2012). Menurut Kemenkes RI (2015) menyatakan bahwa pada tahun 2013, kanker serviks menduduki prevalensi tertinggi di Indonesia sebesar 0,8\% (98.692 kasus). Tidak seperti banyak kanker lainnya, menurut Sankaranarayanan \& Ferlay (2006); Singh, Shetty, Naveed, Pawar, Iska, \& Alugubelli (2016) kanker serviks terjadi pada awal periode reproduksi kehidupan seorang perempuan. Usia rata-rata penderita kanker serviks adalah 38 tahun (usia 21-67 tahun) dengan kejadian yang meningkat pada usia 30-34 tahun dan memuncak pada 55-65 tahun.

Kanker termasuk jenis penyakit kronis dengan berbagai gejala sepanjang hidup pasien. Proses adaptasi terhadap gejala merupakan bagian penting yang menjadi tanggung jawab pasien dengan penyakit kronis yang kompleks, seperti kanker serviks (NRC, 2011; Rechel, Doyle, Grundy, McKee, 2009). Rekomendasi World Health Organisation (WHO) untuk intervensi pengelolaan gejala dimulai pada saat diagnosis berlanjut sepanjang proses penyakit untuk meningkatkan kualitas hidup (CDC, 2011; WHO, 2011). Selain itu, WHO juga menghormati otonomi pasien dalam membuat pilihan dan mengambil peran aktif dalam menyusun rencana pengelolaan gejala (WHO, 2011).

Model konservasi Levine dapat membantu proses adaptasi untuk mencapai kemandirian pasien dalam mengelola kehidupannya secara normal agar dapat bertahan dan meningkatkan status kesehatannya. Model konservasi menurut Schaefer (1996) memberikan gambaran secara logis dan 
praktis melalui eksplorasi pengalaman dan tindakan yang dapat membantu pasien untuk mencapai kenyamanan dengan penyakit yang diderita. Menurut Peterson \& Bredow (2009); Resnick (2005) menyatakan bahwa respon pasien terhadap tindakan yang diberikan selalu dievaluasi dan memperhatikan serta menjaga nilai-nilai perempuan sebagai individu pasien dengan penyakit kronis yang unik berdasarkan pengalaman masing-masing melalui pendekatan model efikasi diri Resnick.

Baru-baru ini, Kebijakan Kanker Nasional yang disponsori oleh Institute of Medicine menekankan bahwa proses adaptasi terhadap gejala sebagai kebutuhan penting untuk meningkatkan perawatan pasien kanker (Institute of Medicine, 2011). Hasil penelitian mengungkapkan bahwa program pengelolaan gejala pasien dengan penyakit kronis di seluruh dunia (Amerika Serikat, Cina, Taiwan, Australia) dapat meningkatkan hasil kesehatan (Dongbo, Hua, \& McGowan, 2003).

Pasien dengan penyakit kronis menurut ONS (2011) diharapkan dapat beradaptasi melakukan pengelolaan gejala. Beberapa dilengkapi dengan kemampuan untuk melakukannya, namun ada juga yang mengungkapkan ketidaksiapan dalam mengelola gejala. Informasi kesehatan sangat penting untuk pasien, berupa mempromosikan rasa kontrol, menurunkan tekanan emosional, mendukung proses adaptasi yang efektif, dan menghilangkan gangguan dari aktivitas sehari-hari (Institute of Medicine, 2011; Skala, Bakitas, Furstenberg, Ahles, \& Henderson, 2004; Sun, Borneman, \& Koczywas, 2011).

Pasien ingin sebanyak mungkin mendapatkan informasi tentang gejala dan strategi untuk mengelolanya (Balmer, 2005; Mack, Weeks, \& Wright, 2010). Akan tetapi, meskipun dengan informasi yang memadai, tidak semua orang memiliki kemampuan yang sama, misalnya dua pasien dengan demografi yang sama, kanker yang sama, dan profil gejala yang sama mungkin memiliki kemampuan yang jelas berbeda untuk mengelola gejala (Glattacker, Heyduck, \& Meffert, 2011; Peppercorn, Smith, Helft, 2011). Resnick (2005) menyatakan bahwa faktor yang berkontribusi terhadap perbedaan pengelolaan diri terhadap gejala adalah efikasi diri individu atau personal selfefficacy (PSE).

Efikasi diri membentuk dasar dari setiap keputusan untuk bertindak dan didefinisikan sebagai persepsi kemampuan sendiri untuk menerapkan perilaku mencapai hasil seperti manajemen gejala. Efikasi diri bukan merupakan ciri kepribadian atau bahkan pandangan yang positif, namun berfokus untuk mencapai tujuan yang ditetapkan atau diharapankan. Efikasi diri dianggab sebagai faktor sentral dan persuasif dalam menentukan tindakan yang dipilih, tingkat usaha yang diberikan, dan ketekunan untuk terus dapat menghadapi kesulitan (Resnick \& Jenkins, 2000; Resnick, 2005). 
Model konservasi Levine dan efikasi diri Resnick membantu perawat melalui kerangka kerja yang mewakili pandangan individu secara holistik, aktif, dan mandiri. Model ini juga melibatkan partisipasi secara aktif dari pasien dalam menyusun rencana keperawatan dan menentukan program perawatan kesehatan yang disesuaikan dengan tujuan akhir yang ingin dicapai (Schaefer, 1996; Hoffman, 2013).

\section{PEMBAHASAN}

Kanker serviks menurut Bermudez, Bhatla, \& Leung (2015) merupakan salah satu penyakit kronik pada perempuan dengan berbagai gejala sepanjang hidup pasien. Pasien dengan kanker serviks pada umumnya menunjukkan gejala perdarahan pervaginam (kontak atau di luar masa haid). Karakteristik pasien (umur, kondisi penyakit kronis, seks, dan stadium kanker) secara fisiologis dipengaruhi oleh gejala. Karakteristik ini berhubungan dengan tingkat keparahan dan kelelahan pasien (Hoffman, 2013).

Perempuan dengan penyakit kronik menurut Schaefer (1996) mengekspresikan kebutuhan secara berkesinambungan untuk belajar mengelola kehidupannya secara normal agar dapat bertahan dan meningkatkan status kesehatan. Pendekatan asuhan keperawatan berdasarkan teori konservasi Levine memfasilitasi proses adaptasi dan membantu mempertahankan status kesehatan secara konsisten sesuai dengan kebutuhan perempuan dengan penyakit kronik. Sedangkan proses mengelola gejala pasien menurut Hoffman (2013) sangat dipengaruhi oleh efikasi diri pasien. Efikasi diri menurut Resnick (2005) merupakan keyakinan penilaian diri terhadap kemampuan keberhasilan dalam melakukan manajemen diri terhadap gejala. Hal ini sangat penting karena berpengaruh positif terhadap hasil kesehatan yang optimal.

Model konservasi Levine dan efikasi diri Resnick membantu perawat melalui kerangka kerja yang mewakili pandangan individu secara holistik, aktif, dan mandiri. Model ini juga melibatkan partisipasi secara aktif dari pasien dalam menyusun rencana keperawatan dan menentukan program perawatan kesehatan yang disesuaikan dengan tujuan akhir yang ingin dicapai (Schaefer, 1996; Hoffman, 2013; Resnick, 2005).

Perawat dapat mengidentifikasi daerah-daerah peningkatan efikasi diri yang dapat memiliki dampak terbesar pada kemampuan seseorang untuk mengelola gejala dan memaksimalkan hasil kesehatan. Penilaian awal efikasi diri memberikan informasi penting untuk menentukan rencana intervensi pasien yang disesuaikan dengan kebutuhan. Selain itu, penilaian berkelanjutan efikasi diri membantu perawat dan pasien memahami dampak intervensi terhadap pencapaian kontrol gejala dan peningkatan hasil kesehatan (Hoffman, 2013; Peterson \& Bredow, 2009). 
Asuhan keperawatan melalui pendekatan teori konservasi Levine dan efikasi diri Resnick merupakan tindakan konservasi yang secara bersama-sama mempertahankan fungsi dan untuk meningkatkan status kesehatan pasien dengan memperhatikan efikasi diri pasien dalam melakukan pengelolaan terhadap gejala. Proses keperawatan dimulai dengan pengkajian secara menyeluruh dengan memperhatikan faktor lingkungan internal (fisiologis dan patologis), lingkungan eksternal (perseptual, operasional, konseptual), prinsip konservasi, dan faktor yang mempengaruhi efikasi diri pasien. Penilaian efikasi diri menurut Resnick (2000); Peterson \& Bredow (2009) dilakukan melalui pengkajian pasien secara langsung terhadap pengalaman pribadi, orang lain, persuasi secara verbal, dan kondisi fisiologis serta psikologis. Sedangkan pendekatan teori Levine menurut Alligood (2014); Cox (2003) berdasarkan pada 4 prinsip konservasi (konservasi energi, integritas struktural, integritas personal, dan integritas sosial). Integrasi kedua teori terutama dalam proses pengkajian, yaitu merawat mendapatkan data secara holistik pada integritas structural dan personal melalui sumber efikasi diri pasien yang terdiri dari keempat sumber tersebut.

Perawat melakukan pengkajian terhadap pasien kanker serviks dengan perdarahan melalui wawancara dan observasi terhadap perubahan lingkungan yang berhubungan dengan prinsip-prinsip konservasi. Selain itu, perawat juga melakukan observasi respon organismik pasien terhadap penyakit (Alligood, 2014; Cox, 2003). Pengkajian lingkungan internal pada pasien kanker serviks dengan perdarahan, meliputi adanya perubahan fisiologis dan patologis (perdarahan pervaginam, dysplasia atau tumor serviks, metastase kelenjar limfe, metastase organ jauh, perubahan fungsi organ reproduksi akibat proses penyakit dan tindakan medis). Selain itu, juga didukung oleh hasil pemeriksaan penunjang, seperti pemeriksaan patologi anatomi, hematologi, foto thorax, EKG, USG, rektoskopi, sistoskopi, dan BNO-IVP.

Pengkajian lingkungan eksternal pada pasien kanker serviks dengan perdarahan menurut Alligood (2014) dibedakan menjadi tiga, yaitu perseptual (tingkat pendidikan, tingkat ekonomi, geografis daerah, ketersediaan sumber dan media informasi, sumber pelayanan dan akses kesehatan, serta teknologi), operasional (faktor risiko kanker serviks dari pasien dan pasangan), dan konseptual (aspek budaya, nilai, karakteristik pandangan spiritual, bahasa, dan gaya hidup). Sedangkan pengkajian prinsip konservasi terbagi menjadi empat prinsip (energi, struktural, personal, sosial). Konservasi energi merupakan bagian integral dari rentang individu dalam melakukan proses penyesuaian (adaptif) terhadap perubahan yang mempengaruhi kemampuan pasien kanker serviks dengan perdarahan untuk dapat tetap beraktivitas secara mandiri, meskipun mengalami kelemahan, anemia, mual muntah, penurunan asupan oral, penurunan BB, ketidakstabilan termoregulasi, dan peningkatan level nyeri abdomen bawah. 
Konservasi integritas struktural tergantung pada sistem pertahanan yang mendukung perbaikan dan penyembuhan dalam menanggapi respon dari lingkungan internal dan eksternal (Alligood, 2014; Levine, 1996). Pada kanker serviks dengan perdarahan, meliputi proses maligna serviks (pemeriksaan inspeksi genitalia eksterna, keluaran pervaginam, nyeri abdomen bawah, punggung, atau tungkai, pembesaran kelenjar getah bening ingunalis, perubahan pola BAB dan BAK, serta pembengkakan ekstremitas). Selain itu, hal yang penting untuk diperhatikan yaitu cara pasien dan keluarga dalam mengatasi perubahan yang terjadi.

Konservasi integritas personal menurut Alligood, 2014; Levine (1996); Resnick (2005) mengakui keutuhan individu dalam menanggapi lingkungan sebagai individu yang berusaha untuk mendapatkan pengakuan, penghormatan, kesadaran diri, kemanusiaan, kemandirian, kebebasan, dan penentuan nasib sendiri berdasarkan efikasi diri pasien. Beberapa aspek yang dikaji, yaitu riwayat pengalaman pertama kali ketika pasien terdiagnosa kanker serviks, adanya perasaan sedih, cemas, takut, depresi, harapan, pengambilan keputusan, dan mekanisme koping pasien dan keluarga selama menjalani perawatan.

Konservasi integritas sosial menurut Alligood (2014); Levine (1996) mengakui fungsi individu dalam masyarakat yang membantu menetapkan batas-batas diri. Integritas sosial dibuat dengan keluarga dan teman-teman, tempat kerja dan sekolah, agama, pilihan pribadi, budaya, dan etnis/keturunan. Perawat mengkaji adanya perasaan kesepian, berpisah dengan pasangan dan/atau anggota keluarga lainnya, perubahan peran, ketidakmampuan melakukan pekerjaan sehari-hari, penurunan/ketidakmampuan melakukan pekerjaan sebelumnya, menarik diri, isolasi sosial, penurunan aktivitas sosial masyarakat, dan pandangan masyarakat sekitar tempat tinggal pasien dan keluarga. Selain itu, perawat juga mengkaji mekanisme koping pada pasien dan keluarga, masalahmasalah yang dialami pasangan atau keluarga selama merawat keluarga dengan kanker serviks dengan perdarahan, upaya yang sudah dilakukan dan harapan keluarga.

Sistem perawatan kesehatan merupakan bagian dari sistem sosial individu dengan adanya kontrol politik dan ekonomi. Levine (1991) menyatakan bahwa model konservasi dalam asuhan keperawatan merupakan bagian penting untuk menjamin keutuhan dan memberikan kekuatan yang dibutuhkan untuk menghadapi penyakit dan kecacatan.

Proses keperawatan berdasarkan manifestasi klinis, masalah, dan kebutuhan pasien terhadap tindakan keperawatan, kemudian ditegakkan diagnosa keperawatan sebagai justifikasi masalah (Trophicognosis). Setelah menentukan Trophicognosis maka dilanjutkan dengan membuat hipotesis keperawatan. Menurut Alligood (2014) menyatakan bahwa hipotesis keperawatan merupakan inti dari rencana keperawatan yang didasarkan pada rumusan masalah sebelumnya. Intervensi 
keperawatan didasari oleh hasil validasi perawat dengan pasien dan keluarga tentang masalah yang dihadapi.

Perawat kemudian menentukan hipotesis dan solusi terhadap permasalahan tersebut. Rencana intervensi berdasarkan teori Levine menurut Alligood (2014); Cox (2003) disusun berdasarkan pada prinsip konservasi. Tujuan intervensi keperawatan, yaitu pencapaian terhadap wholeness dan adaptasi secara berkesinambungan. Implementasi keperawatan berdasarkan prinsip konservasi dalam pernyataan hipotesis keperawatan. Efikasi diri menurut Resnick (2000) dapat mengubah pandangan seorang individu menjadi pribadi yang confident, yaitu individu yang menganggap kondisi sulit sebagai tantangan untuk dapat diselesaikan. Individu tersebut akan lebih berkomitmen dalam berusaha untuk mencapai tujuan yang telah ditentukan.

Implementasi keperawatan menurut Alligood (2014) tergabung dalam wacana intervensi keperawatan yang bertujuan untuk menguji hipotesis (hypothesis testing) dalam mengatasi masalah keperawatan. Implementasi ini difokuskan pada respon organismik pasien (hypothesis testing). Respon organismik dan integritas individu merupakan bagian yang penting dalam proses adaptasi. Proses adaptasi merupakan proses perubahan individu berusaha untuk mempertahankan integritasnya. Proses adaptasi pada konservasi Levine berupa tingkatan dan bukan merupakan proses berhasil atau gagal, sehingga dalam konsep konservasi tidak terdapat proses maladaptasi (Alligood, 2014).

Respon organismik terdiri dari respon penolakan; inflamasi merupakan respon yang memberikan kontinuitas struktural dan mempromosikan penyembuhan; respon stres yang berkembang dapat menyebabkan kerusakan sistem jika dibiarkan secara berkepanjangan; respon persepsi sebagai hasil dari konversi pengalaman pengamatan terhadap lingkungan. Keseluruhan respon secara bersama mempertahankan integritas individu sebagai komponen penting dari keseluruhan respon individu. Tujuan dari perawatan pasien adalah mempromosikan adaptasi dan kesejahteraan (Alligood, 2014). Model konservasi dan efikasi diri memberikan gambaran secara logis dan praktis melalui eksplorasi pengalaman dan tindakan yang dapat membantu pasien untuk beradaptasi dan mencapai kenyamanan hidup. Respon pasien terhadap tindakan yang diberikan selalu dievaluasi dan memperhatikan nilai-nilai perempuan sebagai individu pasien dengan penyakit kronis yang unik berdasarkan pengalaman masing-masing individu (Alligood, 2014; Hoffman, 2013; Schaefer, 1996; Resnick, 2005).

Perawat dapat memberikan wawasan yang dapat mempengaruhi pengalaman total gejala. Proses pemahaman terhadap faktor yang mempengaruhi pengalaman gejala berguna untuk lebih memberdayakan pasien untuk mengelola gejala. Seorang perawat harus mempertimbangkan 
berbagai faktor yang berkontribusi terhadap kemampuan pasien untuk mengelola gejala. Faktorfaktor ini termasuk fisiologis, psikologis, dan kontekstual karakteristik pasien ketika memilih intervensi yang bermanfaat untuk meningkatkan pengaruh yang terbaik dari efikasi diri pasien untuk beradaptasi dan melakukan pengelolaan terhadap gejala secara mandiri (Resnick, 2005; Schaefer, 1996; Hoffman, 2013). Kemandirian pasien berpengaruh positif terhadap gejala pada pasien kanker serviks dengan perdarahan.

\section{SIMPULAN DAN IMPLIKASI PENELITIAN}

Penerapan teori keperawatan konservasi dan efikasi diri membantu perawat maternitas untuk dapat melakukan asuhan keperawatan secara holistik, aktif, dan mandiri pada pasien kanker serviks dengan perdarahan. Integrasi kedua teori menghasilkan pendekatan berdasarkan prinsip konservasi dan komponen efikasi diri yang merupakan bagian dari konservasi personal. Hasil integrasi teori tersebut dapat memfasilitasi proses adaptasi dan membantu mempertahankan status kesehatan secara konsisten.

\section{DAFTAR PUSTAKA}

Alligood, M.R. (2014). Nursing theory: Utilization \& Application. St. Louis Missouri: Mosby Elsivier.

Asiedu, G.B., Breitkopf, C.R., \& Breitkopf, D.M. (2014). Perceived risk of cervical cancer among low-income women. Journal of Lower Genital Tract Disease, 18(4), 304-308. Retrieved from: http://doi.org/10.1097/LGT.0000000000000015.

Balmer, C. (2005). The information requirements of people with cancer. Cancer Nursing, 28,36-44.

Bal, M.S., Goyal, R., Suri, A.K., \& Mohi, M.K. (2012). Detection of abnormal cervical cytology in Papanicolaou smears. J Cytol, 29(1):45-7.

Beral, V. (2015). Reprint of "cancer of the cervix: A sexually transmitted infection?".Cancer Epidemiology, 39(6), 1148-1151. doi:http://dx.doi.org/10.1016/j.canep.2015.08.005

Bermudez, A., Bhatla, N., Leung, E. (2015). Cancer of the cervix uteri. International Journal of Gynecology and Obstetrics, 131, S88-S95.

Centers for Disease Control and Prevention. (2011). Chronic disease: The power to prevent, the call to control. Retrieved from: http://www.cdc.gov/nccdphp/publications/AAG/chronic.htm. [Accessed December 17, 2015]. 
Cox, R. (2003). Using NANDA, NIC, and NOC with Levine's conservation principles in a nursing home. International Journal of Nursing Terminologies \& Classifications, 1441-41 1p.

Dongbo, F., Hua, F., \& McGowan, P. (2003). Implementation and quantitative evaluation of chronic disease self-management programme in Shanghai China: Randomized controlled trial. Bull World Health Organ, 81: 174-182.

Glattacker, M., Heyduck, K., \& Meffert, C. (2011). Illness beliefs, treatment beliefs and information as starting points for patient information evaluation of an intervention for patients with chronic back pain. Patient Educ Couns, 201110.1016/j.pec.2011.05.028.

Gupta, S., Sitimani, A., \& Gupta, A. (2015). Public awareness about cancer cervix and human papilloma virus vaccines. Journal of SAFOMS,3(1), 1-2. Retrieved from http://search.proquest.com/docview/1774305209?accountid=17242

Hoffman, A. J. (2013). Enhancing Self-Efficacy for Optimized Patient Outcomes through the Theory of Symptom Self-Management. Cancer Nursing,36(1), E16-E26. http://doi.org/10.1097/NCC.0b013e31824a730a.

Institute of Medicine. (2011). The national cancer policy summit: Opportunities and challenges in cancer research and care. Washington, DC: The National Academies Press.

Institute of Medicine. (2011). Patients charting the course: Citizen engagement and the learning helath system: Workshop summary. Washington, DC: The National Academy Press.

Kemenkes RI. (2015). Infodatin: Pusat data dan informasi Kementerian Kesehatan RI tentang informasi penyakit kanker. Jakarta: Kemenkes Republik Indonesia.

Levine, M. E. (1966a). Adaptation and assessment: A rationale for nursing intervention. American Journal of Nursing, 66, 2450-2453.Levine, M. E. (1973a). Introduction to clinical nursing (2nd ed.). Philadelphia: F. A. Davis

Levine, M.E. (1991). The conservation model: A model for health. In K. M. Schaefer \& J. B. Pond (Eds.), The conservation model: A framework for nursing practice (pp. 1-11). Philadelphia: F. A. Davis

Levine, M. E. (1996). The conservation principles: A retrospective. Nursing Science Quarterly, 9(1), 38-41.

Mack, J., Weeks, J., \& Wright, A. (2010). End-of-life discussions, goal attainment, and distress at the end of life. Predictors and outcomes of receipt of care consistent with preferences. J Clin Oncol, 28,1203-1208.

Miller, R. A., M.D., Waters, L. L., M.D., Mody, D. R., M.D., \& Tams, K. C., M.D. (2015). Squamous cell carcinoma of the cervix: A cytology-histology-human papillomavirus correlation in clinical practice. Archives of Pathology \& Laboratory Medicine, 139(6), 
776-781.

Retrieved

from

http://search.proquest.com/docview/1688453758?accountid=17242.

Oncology Nursing Society. (2011). ONS 2016-2018 Strategic Plan. Retrieved from: www.ons.org/about/StrategicPlan [Accessed May 31, 2016].

Pandey, D., Shetty, J., Sambhaji, C., Saxena, P., Mishra, D., \& Chawla, A. (2015). Cervical cancer as a silent killer: A rare case report with review of literature.Journal of Cancer Research and Therapeutics, 11(3) doi:http://dx.doi.org/10.4103/0973-1482.137997.

Peppercorn, J., Smith, T., Helft, P. (2011). American Society of Clinical Oncology Statement: Toward individualized care for patients with advanced cancer. J Clin Oncol, (29):755760.

Peterson, S.J. \& Bredow, T.S. (2009). Middle range theories: Application to nursing research, $2^{\text {nd }}$ Edition. Philadelphia: Lippincott Williams \& Wilkins.

Rechel, B., Doyle, Y., Grundy, E., McKee, M. (2009). Policy Brief: How can health systems respond to population ageing?. Copenhagen: European Observatory on Health Systems and Policies.

Resnick, B. (2005). Reliability and validity of the Outcome Expectations for Exercise Scale-2. J Aging Phys Act, 13(4), 382-94.

Resnick, B. \& Jenkins, L. (2000). Reliability and validity testing of the self-efficacy for exercise scale. Nursing research, 49, 154-159.

Sankaranarayanan, R. \& Ferlay, J. (2006). Worldwide burden of gynaecological cancer: the size of the problem. Best Pract Res Clin Obstet Gynaecol, 20(2):207-25.

Schaefer, K.M. (1996). Levine's conservation model: Caring for woman with chronic illness. In P.H. Walker \& B. Neuman (Eds.), Blueprint for use nursing models: Education, research, practice, and administration (pp.187-228). New York: National League for Nursing Press.

Singh, R., Shetty, N., Naveed, M., Pawar, S. B., Iska, S., \& Alugubelli, N. R. (2016). Retrospective analysis of patients with carcinoma cervix in a rural/semi-urban setting in Western India. Indian Journal of Medical and Paediatric Oncology: Official Journal of Indian Society of Medical \& Paediatric Oncology,37(1), 25-27. http://doi.org/10.4103/0971-5851.177011

Skalla, K., Bakitas, M., Furstenberg, C., Ahles, T., \& Henderson, J. (2004). Patient's need for information about cancer therapy. Oncology Nursing Forum, 31, 313-319.

Sun, V., Borneman, T., \& Koezywas, M. (2011). Quality of life and barriers to symptom management in colon cancer. Eur J Cancer Care, in press.

Torre, L.A., Bray, F., Siegel, R.L., Ferlay, J., Lortet, T.J., \& Jemal, A. (2012). Global cancer statistics, 2012. CA Cancer J Clin, 65(2), 87-108. 
World health Organization. (2011). Cancer control knowledge into action world health organization guide for effective programmes: Diagnosis and treatment. Retrieved from: $\quad \underline{\text { http://www.who.int/cancer/modules/FINAL_Module_4.pdf }}$ [Accessed December 2, 2015]

World health Organization. (2011). Noncommunicable diseases mortality and morbidity. Retrieved from: http://www.who.int/gho/ncd/mortality_morbidity. [Accessed December 2, 2015]. 